\title{
PERAN PEMERINTAH DAERAH DALAM PENGEMBANGAN OBYEK WISATA HUTAN BATU RAMMANG - RAMMANG DI KABUPATEN MAROS
}

\author{
Harnida1, Muhammad Tahir ${ }^{2}$ \\ ${ }^{1}$ Program Studi Ilmu Pemerintahan Fakultas Ilmu Sosial dan Ilmu Politik \\ Universitas Muhammadiyah Makassar \\ Jl. Sultan Alauddin No. 259 Makassar 90221 \\ Telp. 0411-866972 ext.107.Fax.0411-8655888 \\ harnida@gmail.com \\ 2Program Studi Ilmu Administrasi Negara Fakultas Ilmu Sosial dan Ilmu Politik \\ Universitas Muhammadiyah Makassar \\ Jl. Sultan Alauddin No. 259 Makassar 90221 \\ Telp. 0411-866972 ext.107.Fax.0411-8655888 \\ muhammadtahir@gmail.com
}

\begin{abstract}
This study aims to determine the role of local governments in the development of forest tourism rammang rammang stone- Maros and determine the government's efforts in the development of tourism rammang-rammang stone forests Maros, using role government indicator as a facilitator, regulator and mediator. This research is qualitative research type phenomenology. Data were collected using such instruments; Observation, interviews and document searches. The results of this study indicate that in general the role of government in the development of tourism rammang rammang-stone forest in Maros is not maximized. As a facilitator, the government has not been much to facilitate the activities of local communities. As a mediator, local governments lack the desire and complaints from people in the area related to the improvement of facilities and infrastructure. As a regulator, the local government has not communicating about the rules of preservation of these attractions.
\end{abstract}

Keywords: role, local government, forest stone

\section{ABSTRAK}

Penelitian ini bertujuan untuk mengetahui peran pemerintah daerah dalam pengembangan obyek wisata Hutan Batu Rammang-rammang Kabupaten Maros dan mengetahui upaya pemerintah dalam pengembangan obyek wisata hutan batu rammang- rammang Kabupaten Maros dengan menggunakan indicator pemerintah sebagai fasilitator, regulator dan mediator. Jenis penelitian ini bersifat kualitatif dengan tipe penelitian fenomenologi. Data dikumpulkan dengan menggunakan instrumen berupa; Observasi, wawancara dan penelusuran dokumen. Hasil Penelitian ini menunjukkan bahwa secara umum peran pemerintah dalam pengembangan obyek wisata hutan batu rammang- rammang di Kabupaten Maros belum maksimal. Sebagai fasilitator, pemerintah belum banyak memfasilitasi aktifitas masyarakat setempat. Sebagai mediator, pemerintah daerah kurang keinginan dan keluhan dari masyarakat di daerah tersebut terkait peningkatan sarana dan prasarana. Sebagai regulator, pemerintah daerah juga kurang berkomunikasi mengenai aturan pelestarian obyek wisata tersebut.

Kata Kunci : Peran, Pemerintah daerah, hutan batu 


\section{A. PENDAHULUAN}

Indonesia sebagai negara kepulauan memiliki kekayaan alam yang melimpah dengan berbagai macam kebudayaan, adat, serta agama yang tentunya dapat dimanfaatkan dalam bidang kepariwisataan sebagai sektor komoditi yang sangat baik bagi perekonomian dan sebagai penghasil devisa negara kedua setelah minyak bumi dan gas alam.

Sejak tahun 1978 pemerintah terus berusaha mengembangkan kepariwisataan dalam meningkatkan penerimaan devisa, memperluas lapangan kerja, dan memperkenalkan kebudayaan. Pembinaan serta pengembangan pariwisata dilakukan dengan tetap memperhatikan terpeliharanya kebudayaan dan kepribadian nasional. Untuk itu perlu diambil langkah-langkah dan pengaturan-pengaturan yang lebih terarah berdasarkan kebijaksanaan yang terpadu, antara lain bidang promosi, penyediaan fasilitas serta mutu, dan kelancaran pelayanan.

Pelaksanaan otonomi daerah di Indonesia yang didasarkan pada UndangUndang Nomor 32 Tahun 2004 yang telah diubah menjadi Undang-Undang 12 Tahun 2008 tentang Pemerintahan Daerah merupakan landasan bagi Pemerintah Daerah dalam menjalankan roda pemerintahan di daerahnya. Otonomi daerah menciptakan ruang gerak yang lebih bebas dalam membuat kebijakan dan peraturan daerah yang melibatkan pihak-pihak terkait yang sesuai dengan pemahaman dan kebutuhan masyarakat masing-masing daerah tersebut, tidak terkecuali dengan pembangunan sektor kepariwisataan.

Adanya otonomi daerah sangat diharapkan daerah mampu memainkan peranannya dalam membuka peluang memajukan daerahnya dengan melakukan identifikasi dan mengelola sumber-sumber yang berpotensi untuk dapat meningkatkan pendapatan asli daerah, karena besar kecilnya pendapat daerah sangat berefek kepada keberhasilan pelaksanaan otonomi tersebut.Hal ini berkaitan erat dengan konsep otonomi dan desentralisasi yang pada hakekatnya memberikan kekuasaan, kewenangan dan keleluasaan kepada pemerintah daerah.
Berdasarkan UU Nomor: 33 Tahun 2004 tentang Perimbangan Keuangan antara Pemerintah Pusat dan Pemerintah Daerah, bahwa sumber-sumber penerimaan dalam rangka pelaksanaan otonomi daerah dan desentralisasi terdiri dari PAD (Pendapatan Asli Daerah), Dana Perimbangan, dan lain-lain penerimaan yang sah dan juga tentang hubungan keuangan, pelayanan umum, pemanfaatan sumber daya alam, dan sumber daya lainya yang harus dilaksanakan secara adil dan selaras. Maka salah satu sektor yang potensial adalah pariwisata, yang kiranya dapat menjadi aset bagi peningkatan pendapatan daerah, yang berujung kepada keberhasilan pemerintah daerah merealisasikan otonomi daerah, yang ditandai dengan terciptanya kesejahteraan yang merata didalam masyarakat.

Pengembangan sektor pariwisata merupakan suatu tindakan yang realistis dan logis, mengingat dampak positif yang ditimbulkan diantaranya semakin meluasnya kesempatan usaha, baik hotel, biro perjalanan, toko cinderamata serta meningkatnya pendapat masyarakat dan mendorong terpeliharanya keamanan dan ketertiban walaupun sebenarnya "juga" ada hal-hal yang berdampak negatif.

Beberapa kebijakan pemerintah dalam sektor pariwisata diantaranya Pembinaan dan Pengembangan Kepariwisataan seperti: menggencarkan promosi pariwisata, meyiapkan dan meningkatkan mutu pelayan dan mutu produk wisata, mengembangkan kawasankawasan pariwisata dan produk-produk baru terutama di wilayah timur Indonesia, meningkatkan kualitas SDM (Sumber Daya Manusia) di bidang kepariwisataan dan melaksanakan kampanye nasional yang berkesinambungan.

Sebagaimana diamanatkan Undang-Undang Dasar Negara Republik Indonesia Tahun 1945, wilayah kesatuan Republik Indonesia dibagi atas daerah provinsi dan daerah provinsi dibagi lagi atas daerah kabupaten dan kota, yang masing-masing sebagai daerah otonomi. 
Sebagai daerah otonomi, daerah provinsi, kabupaten/kota memiliki pemerintahan daerah yang melaksanakan, fungsi-fungsi Pemerintahan Daerah, yakni Pemerintahan Daerah dan DPRD. Kepala Daerah adalah Kepala Pemerintahan Daerah baik didaerah provinsi,maupun kabupaten/kota yang merupakan lembaga eksekutif di daerah, sedangkan DPRD, merupakan lembaga legislatif di daerah baik di provinsi, maupun kabupaten/kota. Kedua-duanya dinyatakan sebagai unsur penyelenggaraan pemerintahan di daerah.

Kabupaten Maros diarahkan sebagai sektor yang dapat diandalkan untuk mendorong pertumbuhan ekonomi masyarakat, peningkatan $\mathrm{PAD}$, pemberdayan masyarakat sekitar, untuk memperluas kesempatan kerja, dan memasarkan produkproduk budaya dalam rangka meningkatkan kesejahteraan masyarakat.Pengembangan kawasan wisata harus terencana, bertahap secara menyeluruh untuk dapat memperoleh manfaat yang optimal bagi masyarakat.

Kabupaten Maros merupakan daerah yang memiliki beberapa obyek wisata salah satunya yaitu obyek wisata hutan batu Rammang- rammang. Objek wisata RammangRammang berada di Gugusan Pegunungan Kapur (karst) Maros-Pangkep, tepatnya berada di Desa Salenrang, Kecamatan Bontoa, Kabupaten Maros, Provinsi Sulawesi Selatan. Berjarak sekitar $40 \mathrm{~km}$ arah utara Kota Makassar, dan bisa ditempuh melalui jalur darat dengan menggunakan kendaraan bermotor dengan waktu tempuh kurang lebih 2 jam perjalanan dari Kota Makassar. Objek wisata ini berupa objek wisata alam dan sangat mudah dijangkau karena hanya beberapa meter dari jalan raya lintas provinsi.

Arti kata Rammang-Rammang sendiri berasal dari bahasa daerah setempat yaitu Bahasa Makassar, di mana kata rammang yang bisa diartikan sebagai awan atau kabut. Sehingga dapat disimpulkan bahwa arti kata rammang-rammang adalah sekumpulan awan atau kabut. Menurut cerita penduduk setempat, tempat ini diberi nama Rammang-Rammang dikarenakan awan atau kabut yang selalu turun terutama di pagi hari atau ketika hujan.

Ada beberapa objek wisata alam yang bisa ditemukan di tempat ini. Yaitu Taman
Hutan Batu Kapur, Telaga Bidadari, Gua Bulu' Barakka', Gua Telapak Tangan, GuaPasaung, dan wisata SungaiPute beserta Kampung Berua. Menurut Sumber yang ada, gugusan karts Maros Ramang ramang ini adalah pegungungan kapur terluas ke 3 yang berada di dunia setelah Cina dan Vietnam. Di Indonesia memiliki taman hutan batu yang eksotik indah, hal ini dikarenakan masing-masing taman hutan batu memiliki karakterisitik dan ciri khas yang berbeda-beda. Dengan ratusan bahkan mungkin ribuan bebatuan kapur berwarna hitam dan abu-abu dengan berbagai bentuk dan ukuran, disekitar perbukitan batu terdapat hamparan sawah penduduk dan di belakangnya terdapat sebuah sungai yaitu Sungai Pute, ditumbuhi pepohonan hutan dan pepohonan lontar di sekitarnya menambah eksotis taman hutan batu di Maros ini. Kawasan ini ibarat sebuah kompleks tempat berkumpulnya bebatuan. Tidak salah rasanya kalau taman hutan batu di Rammang-Rammang ini adalah salah satu yang terindah di dunia.

Berdasarkan penjelasan di atas dapat diketahui bahwa obyek wisata hutan batu rammang-rammang Kabupaten Maros mempunyai banyak daya tarik tersendiri untuk diunjungi karena memiliki banyak keunikan dari beberapa obyek wisata di Sulawesi Selatan bahkan biasa dikatakan salah satu obyek wisata yang terindah di dunia. Akan tetapi, pemerintah daerah kabupaten Maros kurang memperhatikan obyek wisata tersebut salah satu buktinya kebanyakan masyarakat hanya mengetahui obyek wisata bantimrung fasilitas sarana dan prasarana kurang memadai padahal obyek wisata tersebut sangat indah untuk dikunjungi.

Berdasarkan dari klasifikasi pemerintah yaitu sebagai Fasilitator, Regulator dan Mediator kurang menjalankan sebagaimana mestinya misalnya sebagai Fasilitator bukan hanya berperan untuk membantu memfasilitasi aktifitas masyarakat saja untuk mencapai tujuan. Akan tetapi pemerintah juga harus 
secara langsung ke Daerah dalam proses peningkatan pendapatan daerah, hal ini berbanding terbalik dengan keadaan di Kabupaten Maros Tepatnya di Obyek wisata Hutan Batu Rammang- Rammang harusnya tempat tersebut pendapat perhatian dari pemerintah karena obyek wisata tersebut mempunyai keunikan tersendiri untuk di kunjungi dan dapat meningkatkan pendapatan Daerah. Sebagai Regulator pemerintah daerah kurang berkomunikasi dengan masyarakat setempat mengenai obyek wisata tersebut sehingga terkesan diabaikan padahal obyek wisata tersebut sangatlah unik. Sebagai Mediator Pemerintah Daerah kurang merespon apa yang menjadi keinginan dan keluhan dari masyarakat di daerah tersebut terkait peningkatan saranan dan prasrana. Berdasarkan uraian di atas penulis melakukan penelitian mengenai "Peran Pemerintah Daerah dalam pengembangan Obyek Wisata Hutan Batu Rammang- rammagdi Kabupaten Maros. Dan adapun tujuan dari upaya pengembangan obyek wisata Rammang-Rammang Kabupaten Maros.

\section{B. KONSEP PERAN}

Setiap manusia dalam kehidupannya masing-masing memiliki peran dan fungsi dalam menjalankan kehidupan. Dalam melaksanakan perannya, setiap manusia memiliki cara atau sikap yang berbeda-beda. Hal ini sangat dipengaruhi oleh latar belakang kehidupan sosialnya.

Penjelasan selanjutnya mengenai pengertian peran yang dikemukakan olehn Suhardono (1994), bahwa peran sendiri dapat dijelaskan melalui beberapa cara yaitu:

Penjelasan historis, menurut penjelasan historis, konsep peran semula dipinjam dari kalangan yang memiliki hubungan erat dengan drama atau teater yang hidup pada zaman Yunani kuno atau Romawi. Kemudian pengertian peran menurut Ilmu social berarti suatu posisi dalam struktur social tertentu.

Dalam Kamus Besar Bahasa Indonesia (2010),menjelaskan pengertian peran sebagai berikut: Peran adalah pemain yang diandaikan dalam sandiwara maka ia adalah pemain sandiwara atau pemain utama. Peran adalah bagian yang dimainkan oleh seorang pemain dalam sandiwara, ia berusaha bermain dengan baik dalam semua peran yang diberikan. Peran adalah bagian dari tugas utama yang harus dilaksanakan.

Peran merupakan aspek yang dinanis dalam kedudukan (status) terhadap sesuatu. Apabila seseorang melakukan hak dan kewajibannya sesuai dengan kedudukannya, maka ia menjalankan suatu peran (Suharto, 2006). Soekanto (1990) mendefinisikan peran adalah aspek yang dinamis dari kedudukan seseorang dan karena kedudukan itu ia melakukan suatu tindakan atau gerak perubahan yang dinamis dimana dari usaha itu diharapkan akan tercipta suatu keadaan atau hasil yang diinginkan. Tindakan tersebut dijalankan dengan memanfaatkan kewenangan, kekuasaan, serta fasilitas yang dimiliki karena kedudukannya".

Dari sudut pandang yang lain, peranan adalah tindakan yang dilakukan seseorang atas sekelompok orang dalam suatu peristiwa (Poerwadarminta, 1995). Dari berbagai pengertian tersebut dapat ditarik kesimpulan mengenai pengertian peranan dalam hal ini peran pemerintah dalam melaksanakan fungsi dan tujuannya dalam pelayanan, pembangunan, pemberdayaan, dan pengaturan masyarakat. Dapat dijelaskan bahwa peranan merupakan aspek dinamis dari kedudukan apabila seseorang melaksanakan hak-hak serta kewajiban sesuai dengan kedudukannya maka ia telah melakukan sebuah peranan.

Menurut Dougherty dan Pritchard dalam Bauer (2003:55), teori peran ini memberikan suatu kerangka konseptual dalam studi perilaku di dalam organisasi. Mereka menyatakan bahwa peran itu "melibatkan pola penciptaan produk sebagai lawan dari perilaku atau tindakan". Mengemukakan bahwa relevansi suatu peran itu akan bergantung pada penekanan peran tersebut oleh para penilai dan pengamat (biasanya supervisor dan kepala sekolah) terhadap produk yang dihasilkan.

Menurut Soekanto peranan adalah aspek dinamisi kedudukan 
(status). Apabila seseorang melaksanakan hak dan kewajibannya sesuai dengan kedudukannya, maka ia menjalankan suatu peranan.

\section{KONSEP PEMERINTAHAN}

Secara etimologi kata pemerintah berasal dari kata"perintah"yang kemudian mendapat imbuhan awalan "pe"menjadi kata "pemerintahan"berarti badan atau organ elit yang melakukan pekerjaan mengurus suatu Negara. Sedangkan akhiran"an"menjadi kata "pemerintahan" berarti perihal, cara, perbuatan atau urusan dari badan yang berkuasa dan memiliki legitimasi.

Didalam kata dasar "perintah" paling sedikit ada empat unsur penting yang terkandung didalamnya, Thomas dalam Labolo (2011: 25), yaitu sebagai berikut:

1. Ada dua pihak yaitu yang memerintah disebut pemerintah dan pihak yang diperintah disebut rakyat.

2. Pihak yang memerintah memiliki kewenangan dan legitimasi untuk mengatur dan mengurus rakyatnya.

3. Hak yang diperintah memiliki keharusan untuk taat kepada pemerintah yang sah.

4. Antar pihak yang memerintah dengan yang diperintah terdapat hubungan timbal balik secara vertikal maupun horizontal.

Menurut Undang-Undang Nomor 32 Tahun 2004 tentang Pemerintahan Daerah, yang disebut dengan Pemerintah Daerah adalah Kepala Daerah beserta perangkat daerah otonom yang lain sebagai badan eksekutif daerah. Peranan Pemerintah Daerah dalam mendukung suatu kebijakan pembangunan bersifat partisipatif adalah sangat penting. Ini karena Pemerintah Daerah adalah instansi pemerintah yang paling mengenal potensi daerah dan juga mengenal kebutuhan rakyat setempat (Soetrisno, 1995).

Dalam sistem pemerintahan model Rusia, semua lembaga pemerintahan daerah merupakan bagian integral dari birokrasi pemerinahan nasional, peraturan di setiap tingkat didominasi oleh kebijakan partai tungal. Sedangkan pemerintahan daerah model Inggris, mempunyai karakteristik otonomii yang besar, semua kekuatan bertumpu pada dewan, menggunakan komite secara luas (S.H.
Sarundajang, 2001 : 39). Pemerintahan daerah model Rusia sangat bernuansa administratif, berdasar prinsip-prinsip pencapaian fungsi secara efektif dan efisien dengan mengesampingkan nilainilai demokratis. Sementara pemerintahan daerah model Inggris sangat bernuansa politis, sangat memperhatikan nilai-nilai demokratis, sehingga pemerintahan daerah di desain untuk keseimbangan keinginan negara dan masyarakat lokal.

Khusus untuk gejala pemerintahan dapat terjadi bentuk sentralistik yang tirani dan dapat pula berbentuk desentralistik yang mengandalkan demokrasi tetapi beresiko munculnya anarkis. Hubungan antara penguasa dan rakyatnya inilah yang menjadi pusat perhatian ilmu pemerintahan yang apabila dilihat dari perubahan paradigma mutakhir ini, ada yang bernuansa liberal kapitalis yang melahirkan kebebasan mutlak di satu sisi, sedangkan pada sisi yang lain dapat melahirkan sosialisme yang komunis yang diktator ploretariat.

Dalam mengelola pemerintah secara baik dan benar, pemerintah hendaknya jangan hanya sebagai penjaga malam yang mementingkan ketertiban tetapi jangan lupa pada ketentraman dan kesejahteraan, jadi jangan hanya mampu berkuasa tetapi juga mampu untuk melayani. Oleh karena itu disebut sebagai pemerintah yang baik dan benar atau dengan kata lain good governance dan cleant government, ketika pemerintah mengusir pedagang kaki Limadari jalanan protokal maka hal itu adalah benar karena akan mengotori jalan raya menjadi macet. Itulah beberapa hal yang perlu diseimbangkan dalam penyelenggaraan roda pemerintah karena dapat disadari apakah kita akan mengorbankan terlalu banyak anasir etis guna efisiensi, atau apakah sebaliknya kita mengorbankan efesiensi guna memenuhi tuntutan etis.

Menurut Strong dalam Syafii (2009:5), mengemukakan pemerintah dalam arti luas mempunyai kewenangan untuk memelihara kedamaian dan keamanan Negara, kedalam dan keluar. Oleh karena itu pertama harus 
mempunyai kekuatan militer atau kemampuan untuk mengendalikan angkatan perang, yang kedua harus mempunyai kekuatan militer atau kemampuan untuk mengendalikan angkatan perang, yang ketiga harus mempunyai kekuataan legislatif atau dalam arti pembuatan undang-undang, yang keempat harus mempunyai kekuatan finansial atau kemampuan untuk mencukupi keuangan masyarakat dalam rangka membiayai ongkos keberadaan Negara dalam penyelenggaran peraturan, hal tersebut dalam rangka penyelenggaraaan kepentingan Negara.

Menurut Finer dalam Syafii (2009:6), pemerintah harus mempunyai kegiatan yang terus menerus (procces), wilayah Negara tempat kegiatan (state), pejabat yang memerintah (the duty), cara, metode, dan sistem (manner, method and sistem) dari pemerintah terhadap masyarakatnya.

Menurut Iver dalam Syafii (2009:6), mengemukakan bahwa pemerintahan adalah sebagai suatu organisasi dari orang-orang yang mempunyai kekuasaan bagaimana manusia itu diperintah.

Menurut Ndraha dalam Mustafa (2013:86), melalui pendekatan kelembagaan dan pendekatan produk (output) dapat diidentifikasi beberapa pengertian Pemerintah sebagai berikut : (1) Pemerintah adalah badan publik, yaitu semua badan/institusi yang bertanggungjawab dalam sebagian atau seluruh proses penyediaan (providing) suatu jasa atau layanan melalui otorisasi atau privatisasi. (2) Pemerintah dalam arti terluas adalah semua lembaga Negara seperti diatur di dalam UUD (konstitusi) suatu Negara (3) Pemerintah dalam Luas adalah semua lembaga Negara yang oleh konstitusi Negara yang bersangkutan disebut sebagai pemegang kekuasaan pemerintahan. (5) Pemerintah dalam arti sempit yaitu lembaga Negara yang memegang kekuasaan eksekutif saja. (6) Pemerintah dalam arti tersempit, yaitu lembaga Negara yang memegang fungsi birokrasi. Birokrasi adalah aparatur pemerintah yang diangkat atau ditunjuk dan bukan yang dipilih atau terpilih melalui pemilihan oleh lembaga perwakilan. Birokrasi dapat dianggap setara dengan pemerintah, tetapi lebih luas ketimbang pabrik pada perusahaan. (7) Pemerintah dalam arti pelayan, diambil dari konsep civil servant. Di sini pemerintah di anggap sebagai sebuah warung atau toko dan pemerintah adalah pelayan yang melayani konsumen atau pelanggan (pembeli). (8) Pemerintah dalam konsep Pemerintah Pusat, yaitu pengguna kekuasaan negara pada tingkat pusat (tertinggi) pada umumnya dihadapkan pada konsep pemerintah daerah. (9) Pemerintah dalam konsep Pemerintah Daerah. Berbeda dengan pemerintah pusat yang dianggap mewakili Negara, pemerintah daerah dianggap mewakili masyarakat, karena daerah adalah masyarakat hukum yang tertentu batas wilayahnya. (10) Pemerintah dalam konsep Pemerintah Wilayah. Pemerintah dalam arti ini dikenal dalam Negara yang menggunakan asas desentralisasi dan dekonsentrasi, contohnya Indonesia di bawah Undang-undang nomor 32 Tahun 2004 tentang pemerintahan di Daerah. Penyelenggaraan kekuasaan (urusan/kewenangan) pusat di Daerah dikelola oleh pemerintah wilayah. (11) Pemerintah dalam konsep Pemerintah Dalam Negeri, yang berasal dari tradisi Pemerintah Belanda (binnenlandsbestuur) yang dikenal dengan sebutan pamong praja. (12) Pemerintah dalam konteks ilmu pemerintah adalah semua lembaga yang dianggap mampu (normatif) atau secara empirik memproses jasa-publik dan layanan civil.

\section{PERAN PEMERINTAH DAERAH}

Pemerintah daerah dianggap mewakili masyarakat, karena daerah adalah masyarakat hukum yang tertentu batas wilayahnya. Menurut Rasyid (2000:13), peran pemerintahan adalah untuk melayani dan mengatur masyarakat, lebih menekankan upaya mendahulukan kepentingan umum,mempermudah urusan publik dan memberikan kepuasan kepada publik, sedangkan tugas mengatur lebih menekankan kekuasaan power yang melekat pada posisi jabatan birokrasi. Rasyid memaparkan enam tugas umum pemerintah antara lain menjamin keamanan negara dari segala 
kemungkinan serangan dari luar, dan menjaga agar tidak terjadi pemberontakan dari dalam yang dapat menggulingkan pemerintahan yang sah melalui cara-cara kekerasan, memelihara ketertiban dan menjamin agar perubahan apapun yang terjadi di dalam masyarakat dapat berlangsung secara damai, menjamin diterapkannya perlakuan yang adil kepada setiap warga masyarakat, melakukan upayaupaya untuk meningkatkan kesejahteraan sosial, menerapkan kebijakan ekonomi yang menguntungkan masyarakat luas, dan menerapkan kebijakan untuk memelihara sumber daya alam dan lingkungan.

Muluk (2006) menjelaskan menguatnya peran pemerintah bukan berarti tidak akan muncul masalah. Persoalan baru timbul karena pada dasarnya pemerintah juga tidaknsempurna.Kegagalan pemerintah dalam memberikan pelayanan public yang efisien, merata dan memuaskan disebabkan oleh berbagai factor yaitu tidak adanya kaitan langsung antara biaya dan pendapatan, menyebabkan kurang intensifnya pencapaian efisiensi yang lebih besar.

Secara umum peran pemerintah mencakup tiga peran pokok yang seharusnya dijalankan oleh pemerintah baik pemerintah pusat maupun pemerintahdaerah H. Nurul dalam Haryanto (1997:36-37 ). (1) Peran Pengaturan, peran ini dilaksanakan pemerintahan dengan membuat peraturan perundang-undangan untuk mengatur hubungan manusia dalam masyarakat. Pemerintah adalah pihak yang mampu menerapkan peraturan agar kehidupan dapat berjalan secara baik dan dinamis. Seperti halnya peran pemerintah pusat, pemerintah daerah juga mempunyai peran pengaturan terhadap masyarakat yang ada di daerahnya. Perbedaannya, yang diatur oleh pemerintah daerah lebih khusus, yaitu urusan yang telah di serahkan kepada daerah. Untuk mengatur urusan tersebut diperlukan peraturan daerah yang dibuat bersama antara DPRD dengan eksekutif. (2) Peran pelayan umum (public service), peran pelaksanaan yang dilakukan Pemerintah Pusat dan Pemerintah Daerah terletak pada kewenangan masing-masing. Kewenangan Pemerintah Pusat mencakup urusan pertahanan Keamanan, Agama, Hubungan Luar Negeri, Moneter, dan Peradilan.
Secara umum pelayan pemerintahan mencakup pelayanan publik (Public Service) dan pelayanan sipil (Civil Service) yamg menghargai kesetaraan. Pelayanan umum menurut keputusan menteri pendayagunaan aparatur Negara Nomor 63/KEP/M.PAN/7/2003 adalah segala pelayanan kegiatan yang dilaksanakan oleh penyelenggaraan pelayanan politik sebagai upaya pemenuhan kebutuhan penerima pelayanan maupun pelaksanaan ketentuan perundang-undangan. Adapun yang dimaksud penyelenggaraan pelayan publik adalah instansi pemerintah. (3) Peran Pemberdayaan, peran ini untuk mendukung terselenggaranya otonomi daerah, fungsi ini menuntut pemberdayaan Pemerintah Daerah dengan kewenangan yang cukup dalam pengelolaan sumber daya daerah guna melaksanakan berbagai urusan yang di desentralisasikan. Untuk itu Pemerintah Daerah perlu meningkatkan peran serta masyarakat dan swasta dalam kegiatan pembangunan dan penyelenggaraan pemerintah. Kebijakan pemerintah, pusat dan daerah, diarahkan untuk meningkatkan aktivitas ekonomi masyarakat, yang pada jangka panjang dapat menunjung pendanaan Pemerintah Daerah. Dalam fungsi ini pemerintah harus memberikan ruang yang cukup bagi aktivitas mandiri masyarakat, sehingga dengan demikian partisipasi masyarakat di Daerah dapat ditingkatkan.

\section{E. MANAJEMEN PEMERINTAHAN}

Manajemen pemerintahan adalah bagian utama dari bidang kajian Administrasi Negara yang sangat luas. Manajemen pemerintahan berkaitan dengan fungsi- fungsi dan proses manajemen pada semua di bagian tingkatan pemerintahan sebagai sector nirlaba.

Suryadinata ( 1998 ) memandang manajemen pemerintahan sebagai suatu tingkatan atau usaha untuk mencapai tujuan Negara dengan menggunakan berbagai sumber yang dikuasai oleh Negara. Inti manajemen pemerintahan 
terletak pada proses penggerakan untuk mencapai tujuan Negara, dimana terkait erat dengan apa yang kita kenal dengan fungsi kepamongprajaan.

Sebagai suatu ilmu manajemn pemerintahan bersifat sangat sfesifik, hal ini disebabkan oleh adanya unsur publik dan kekuasaan sebagai elemen dasar manajemen pemerintahan, kenyataan ini mengakibatkan manajemen pemerintahan akan banyak terkait dengan pengkajian terhadap berbagai sistem yang lebih luas seperti sistem politik, sistem sosial budaya, sistem ekonomi serta sistem lainnya yang menyangkut masyarakat luas.

Suryadinata (2002) mengemukakan pemerintahan yang merupakan proses kegiatan pemrintahan dalam pelaksanaannya memerlukan manajemen pemrintahan yang berorientasi pada usaha bagi kepentingan pemerintahan dan kepentingan rakyat wiraswasta. Manajemen pemerintahan merupakan proses kegiatan pemerintah yang secara umum berkaitan dengan usaha-usaha menjalankan kekuasaan pemerintahan dalam Negara dengan mengimplementasikan fungsi manajamen.

\section{F. MANAJEMENPENGELOLAAN PARIWISATA}

Berbicara tentang kepariwisataan nasional dalam kaitan dengan ketentuan perundang-undangan mengharuskan kita melihat tiga dimensi sebagai kurun waktu masa lalu, masa sekarang dan masa yang akan datang. Telah menjadi pengetahuan umum bahwa agar penyelenggraan kepariwisataan dapat berhasil dengan baik perlu dimanfaatkan secara tepat komponen yang menjadi pendukungnya. Diantara komponen-komponen tersebut yang telah dimiliki bangsa Indonesia bahkan merupakan modal dasra bagi pengembangan kepariwisataan adalah alam flora dan fauna serta budaya bangsa.Tuhan yang maha Kuasa telah menganugrahkan kepada bangsa kita sebuah tanah air yang berupa kepulauan terbesar di dunia.

Peningkatan sektor pariwisata sebagaimana kedudukannya sekarang ini,merupakan salah satu sektor unggulan (leading sector) dalam perekonomian Nasional yang senantiasa perlu dikembangkan dan ditingkatkan. Jika ditinjaudari aspek sosial ekonomi dapat meningkatkan pendapatan masyarakat, perluasan kesempatan kerja, meningkatkan pendapatan pemerintah, peningkatan penerimaan devisa meningkatkan kewirausahaan Nasional dan turut mendorongpembangunan di daerah.

$$
\text { Undang-Undang }
$$

Republik Indonesia Nomor 10 Tahun 2009 tentang kepariwisataan digariskan bahwa pembangunan pariwisata perlu ditingkatkan untuk memperluas kesempatan kerja dan kesempatan berusaha, meningkatkan penerimaan devisa serta memperkenalkan alam kebudayaan bangsa Indonesia.

Dalam menghadapi perubahan global dan penguatan hak pribadi masyarakatuntuk menikmati waktu luang dengan berwisata, perlu dilakukan pembangunan kepariwisataan yang bertumpu pada keanekaragaman, keunikan, dan kekhasan bangsa dengan tetap menempatkan kebhinekaan sebagai suatu yang hakiki dalam bingkai Negara Kesatuan Republik Indonesia. Selain itu, pembangunan kepariwisataan harus tetap memperhatikan jumlah penduduk. Jumlah penduduk akan menjadi salah satu modal utama

dalampembangunan kepariwisataan pada masa sekarang dan yang akan datang karena memiliki fungsi ganda, di samping sebagai aset sumber daya manusia, juga berfungsi sebagai sumber potensi wisatawan nusantara.

Pembangunan kepariwisataan dapat dijadikan sarana untuk menciptakan kesadaran akan identitas nasional dan kebersamaan dalam keragaman. Pembangunan kepariwisataan dikembangkan dengan pendekatan pertumbuhan dan pemerataan ekonomi untuk kesejahteraan rakyat dan pembangunan yang berorientasi pada pengembangan wilayah, bertumpu kepadamasyarakat, dan bersifat memberdayakan masyarakat yang mencakupiberbagaiaspek, seperti sumber daya manusia, pemasaran, destinasi, ilmu pengetahuan danteknologi, keterkaitan lintas sektor, kerja sama antarnegara, 
pemberdayaan usahakecil, serta tanggung jawab dalam pemanfaatan sumber kekayaan alam danbudaya.

Ditinjau dari segi kebudayaan, sektor pariwisata Indonesia memperkenalkan kebudayaan Indonesia kepada wisata asing. Jadi faktor pariwisata memiliki konstribusi yang cukup besar didalam pembangunan nasional, untuk itu segala potensi yang ada di tanah air perlu dimanfaatkan dengan sebaikbaiknya.

\section{G. METODE PENELITIAN}

Penelitian lapang ini telah dilakukan di Kabupaten Maros. Alasan penulis memilih lokasi tersebut karena melihat Kabupaten Maros merupakan salah satu kabupaten yang memliki obyek wisata yang beragam seperti Bantimurung dan obyek wisata hutan batu Rammang-Rammang. Oleh sebab itulah, penulis tertarik untuk melakukan penelitian tentang Peran Pemerintah Daerah terhadap obyek wisata hutan batu Rammang- rammang di Kabupaten Maros. Adapun Tipe penelitian ini adalah penelitian Fenomenologi yaitu peneliti berusaha untuk mengungkapkan suatu fakta atau realita fenomena sosial tertentu sebagaimana adanya.

Penelitian deskriptif dimaksudkan untuk mengumpulkan informasi mengenai status suatu gejala yang ada. Tujuan penelitian deksriptif adalah untuk membuat penjelasan secara sistematis, faktual, dan akurat mengenai fakta-fakta artinya menjelaskan peran pemerintah Daerah dalam pengembangan obyek wisata hutan batu Rammang-rammang di Kabupaen Maros. Sumber data yang digunakan dalam penelitian ini yaitu mengumpulkan data dari penelitian : Data Primer dan Data sekunder. teknik pengumpulan data yaitu : Observasi, Wawancara, Dokumen/Arsip. Dalam pengujian pengabsahan data, peneliti menggunakan validitas data seagai alat pembuktian bahwa data yang diperoleh peneliti sesuai dengan apa yang benar-benar terjadi di lapangan, untuk menguji validitas data maka peneliti menggunakan metode triangulasi yaitu : Triangulasi Sumber, Triangulasi Tehnik, Triangulasi Waktu

\section{H. HASIL DAN PEMBAHASAN}

\section{Berdasarkan hasil observasi} penulis di lapangan peran pemerintah dalam hal pegembangan obyek wisata hutan batu Rammang-Rammang kurang terlaksana sebagaimana mestinya hal ini dilihat dari kurangnya fasilitas yang tersedia di daerah tersebut seperti halnya dengan penginapan dan akses kendaraan disanakurang memadai masyarakat juga tidak teralu memperhatikan karena kurangya bantuan dari pemerintah yang menangani hal tersebut. Berikut Hasil wawancara penulis dengan masyarakat sekitar objek wisata rammang-rammang:

"Sebenarnya hutan batu di daerah ini sangat bagus dan indah untuk dijadikan tempat rekreasi dan refreshing hal ini di sebabkan oleh Rammang-rammang dikenal karena keindahan sungai yang berada pada sela-sela gugusan karst yang menjulang tinggi. Di sepanjang tepi sungai, Kawasan dengan bentang alam yang sangat eksotis ini memiliki nilai geologi dan arkeologi yang sangat tinggi. Kawasan Karst Rammang-rammang menyimpan banyak bukti sejarah fenomena geologi, wisatawan dapat menyaksikan nipah tumbuh berbaris dan berlapis. apalagi banyak tempat yang menarik perhatian untuk di kunjungi akan tetapi yang hanya mengunjunginya biasa saya liat hanya para pendaki masyarakat umum lainnya jarang sekali mungkin karena faktor transportasi yang kurang mendukung dan sarana tempat istirahat atau penginapannya bisa dibilang tidak ada (wawancara, $A H)^{\prime \prime}$.

Berdasarkan hasil wawancara di atas penulis dapat menyimpulkan bahwa peran pemerintah di obyek wisata hutan batu Rammang-rammang kurang terlaksana dengan baik karena pemerintah terkait kurang memperhatikan salah satu contohnya 
yaitu sarana transportasi masih kurang dan fasilitas penginapannya bisa dikatakan tidak ada, seharusnya pemerintah yang bersangkutan memperhatikan obyek wisata tersebut agar daerah Kabupaten Maros dapat terkenal dengan obyek wisata hutan batu dan secara tidak langsung dapat meningkatkan pendapatan asli daerah.

Berdasarkan hasil pengamatan penulis di lapangan tidak adanya terlihat fasilitas yang memadai dari bantuan pihak pemerintah yang berusaha adalah hasil kerjasama antara pengelola dengan masyarakat setempat seperti halnya dengan tersedianya perahu itu hasil dari masyarakat setempat berikut Hasil wawancara penulis dengan pihak pengelola objek wisata rammang-rammang :

YS Selaku pengelola obyek wisata Hutan Batu Rammang- rammng mengatakan bahwa:

"Berbicara fasilitas yang dibantukan dari pihak pemerintah itu sendiri dek masih kurang memadai atau kah bisa dikatakan masih kurang kami disini sebagai pengelola mengharapkan partisipasi dari pihak pemerintah yang terkait agar lebih memperhatikan obyek wisata ini karena merupakan suatu sset yang perlu dilestarikan seperti contohnya ketersdiaan perahu sangatlah minim" ( Wawancara, YS).

Berdasakan hasil wawancara penulis dapat menyimpulkan bahwamasih kurangnya ketersediaan fasilitas di obyek wisata hutan batu rammang-rammang perlu adanya dari pihak pemerintah yang memperhatikan hal tersebut karena obyek wisata tersebut bisa dikatakan asset yang perlu dikembangkan.

Berdasarkan hasil pengamatan penulis di lapangan masih kurangnya partisipasi dari Dinas terkait hal ini dibuktikan dengan kurang sarana dan prasarana yang tersedia di obyek wisata Hutan batu Rammang- Rammang. Banyak masyarakat yang apabila berkunjunng ke tempat tersebut mengeluh akan fasilitas yang kurang memadai padahal obyek wisata hutan Batu Rammang- Rammang merupakan aset Kabupaten maros yang bagus untuk dikembangkan.

YS Selaku pengelola obyek wisata Hutan Batu Rammang- rammng mengatakan bahwa:
"Sungguh sangat disayangkan apabila obyek wisata ini kurang yang memperhatikan padahal obyek wisata ini sangat indah orang- orang yang berkunjung kesini juga mengatakan hal seperti itu juga. Instansi yang terkait harus dapat memperhatikan hal seperti ini apalagi dari Dinas Pariwisata kabupaten Maros (wawancara,YS).

Berdasarkan hasil wawancara di atas penulis dapat menyimpulkan bahwa masih kurangnya partisipasi dari pihak pemerintah dalam pengembangan obyek wisata Hutan Batu Rammang-Rammang. Masyarakat sangat mengharapkan bantuan dari pihak pemerintah terkait peningkatan sarana dan prasarana agar semakin banyak masyarakat yang tertarik untuk berkunjung di Obyek Wisata Hutan Batu Rammang-Rammang.

Berdasarkan hasil pengamatan penulis di lapangan obyek wisata Hutan Batu Rammang-Rammang memerlukan fasilitas yang dapat menunjang perkembangan obyek wisata tersebut karena merupakan asset yang sangat berharga untuk dikembangkan misalnya meningkatkan aliran listrik, karena salah satu desa tersebut yang biasanya di tempati pengunjung untuk sekedar istirahat aliran listriknya masih kurang memadai.

Berikut Hasil wawancara penulis dengan masyarakat sekitar objek wisata rammang-rammang :mengungkapkan bahwa :

"masyarakat disini masih sangat memerlukan fasilitas yang memadai seperti halnya dengan pengadaan aliran listrik karena fasilitas aliran listriknya masih kurang memadai padahal di desa ini adalah tempat para pengunjung untuk beristirahat, saya masih ingat sekali ada turis yang saya temani dia mengatakan tempat ini sangat indah namun belum begitu tersentuh oleh pemerintah dan masyarakat di luar sana masih banyak yang belum mengetahui tempat ini, turis 
memberikan kami bantuan berupa alat pembangkit listrik tenaga surya itu merupakan hal yang kami inginkan, masyarakat berharap ada bantuan dari pihak pemerintah terkait pengembangan obyek wisata hutan Batu Rammang-Rammang" (wawancara, HS).

Berdasarkan hasil wawancara di atas penulis dapat menyimpulkan bahwa belum memadainya aliran listrik sehingga aktifitas obyek wisata terhambat untuk dikembangkan masyarakat berharapa ada bantuan dari pihak pemerintah terkait pengembangan obyek wisata Hutan Batu Rammang- Rammang.

Berdasarkan hasil Pengamatan penulis di lapangan obyek wisata Hutan Batu Rammang- rammang masih sangat memerlukan perhatian dari dinas terkait dalam hal ini dalam proses pengembangannya ini dapat di lihat dari masih kurangnya pengunjung yang datang dan masih banyaknya yang belum mengetahui obyek wisata tersebut maka perlu adanya partisipasi dari dinas terkait dalam hal melakukan promosio wisata.

Berikut Hasil wawancara penulis dengan pihak pengelola objek wisata Hutan batu rammang- ram mengatakan bahwa :

"Menurut saya partisipasi dinas terkait dalam hal pengembangan obyek wisata hutan batu rammang-rammang sangatlah penting karena dinas terkait mngetahui apa yang harus dilakukan agar obyek wisata ini dapat brkembang dan banyak wisatawan yang datang untuk berkunjung, seperti halnya dengan melakukan promosi di luar (wawancara, $Y S)^{\prime \prime}$.

Berdasarkan hasil wawancara di atas peenulis dapat menyimpulkan bahwa obyek wisata hutan batu rammang-rammang Kabupaten Maros perlu adanya usaha yang dilakukan dinas terkait agar wisatawan yang berkunjung dapat meningkat, salah satu caranya yaitu melakukan promosi wisata ke berbagai media.

Berdasarkan hasil pengamatan penulis di lapangan obyek wisata hutan batu rammangrammang masih sangat nmemerlukan partisipasi dari pihak terkait mengenai pengembangan obyek wisata hutan batu rammang-rammang terutama maslah sarana dan prasarananya, misalnya penginapan, toilet dan lain-lainnya, karena sampai saat ini yang digunakan hanyalah milik masyarakat setempat

Berikut Hasil wawancara penulis dengan pihak pengelola objek wisata rammang-rammang :

"Berbicara masalah sarana dan prasarana di sini masih sangat minim kami masih memerlukan bantuan dari pihak pemerintah dalam peningkatan sarana dan prasarana seperti sarana penginapan,toilet dan lain-lainnya agar pengunjung tertarik untuk datang bukan hanya bantimurung saja yang terkenal (wawancara, YS )".

Berdasarkan hasil wawancara di atas penulis dapat menyimpulkan bahwa masih kurangnya partisipasi dari pihak pemerintah mengenai pengembangan obyek wisata hutan batu rammangrammang Kabupaten Maros hal ini terbukti dari tidak adanya penginapan dan toilet, pengunjung hanya menggunakan sarana tersebut milik masyarakat setempat.

\section{PENUTUP}

Berdasarkan uraian hasil penelitian dan pembahasan, dapat ditarik kesimpulan sehubungan dengan permasahan penelitian yang diajukan sebagai berikut : Peran pemerintah daerah dalam pengembangan obyek wisata hutan batu rammang- rammang masih belum maksimal. Ketika peneliti melihat kondisi di lapangan partisipasi dari pihak pemerintah masih kurang hal ini di tandai dengan tidak adanya sarana yang memadai misalnya dengan sarana toilet, pngunjung hanya menumpang di toilet masyarakat setempat dan terkadang pengunjung beristirahat di rumah warga.Oleh karena itu perlu adanya peran pemerintah daerah dalam pengembangan obyek wisata hutan batu rammang- 
rammang Kabupaten Maros. Upaya pemerintah Daerah dalam pengembangan obyek wisata hutan batu rammang- rammang di kabupaten Maros yaitu : promosi, aktifitas pomosi sangat diperlukan dalam mempromosikan obyek wisata hutan Batu rammang- rammang Kabupaten maros karena dengan melalui aktivitas promosi masyarakat pada umumnya akan tahu tentang obyek wisata yang di promosikan, Akan tetapi aktivitas promosi yang dilakukan dinas terkait masih sangat kurang maka dari itu perlu adanya peningkatan.

Sarana dan prasarana di obyek wisata hutan batu rammang-rammang kabupatem Maros masih sangat kurang, oleh karena itu perlu adanya pihak terkait yang bertanggung jawab mengenai hal terseebut, perlu adanya partisipasi dari pihak terkait yang bekerjasama dengan peengelola serta masyarakat setempat terkait dengan peningkatan sarana dan prasarana.

\section{DAFTAR PUSTAKA}

Syafii, Inu Kencana. 2009. Kepemimpinan Pemerintahan Indonesia. Bandung : Refika

\section{Aditama}

Rasyid. 2000. Peran dan fungsi pemerintah. Di posting pada hari Minggu 22 September 2012 pukul 13.35.http://laurafricilia.blogspot.co $\mathrm{m}$

Soekanto, Soerjono. 2002. Sosiologi Suatu Pengantar. Jakarta : Raja Grafindo Persada.

Suharto, Edi. 2006. Membangun Masyarakat Memberdayakan Rakyat. Bandung : PT. Refika Aditama.

Suryadinata. $1998 . \quad$ Manajemen, Manajemen Pemerintahan. frameit.blogspot.com. diakses tanggal 2 November 2011. 